YEARBOOK

of ANTITRUST

and REGULATORY

STUDIES

www.yars.wz.uw.edu.pl
Peer-reviewed scientific periodical, focusing on legal and economic issues of antitrust and regulation. Creative Commons Attribution-No Derivative Works 3.0 Poland License.

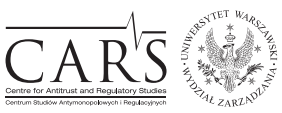

Centre for Antitrust and Regulatory Studies, University of Warsaw, Faculty of Management www.cars.wZ.uw.edu.pl

\title{
Open Access Competition in the Long-Distance Passenger Rail Services in Poland
}

\author{
by
}

Marcin Król*

\section{CONTENTS}

I. Introduction

II. Evidence

III. Discussion and conclusions

\section{Abstract}

This paper presents evidence of the head-on open access competition which took place on the market of long-distance passenger rail services in Poland in 2009-2015. The regional governments-owned challenger managed to raise its market share to more than 33\% (2010) but eventually was forced out of the market (2015) due to a sudden change in its business strategy as well as the incumbent's strategic pressure on the political and regulatory decision-makers. This case has not featured yet in the scientific discussion on the open access in the passenger rail markets in Europe and the main aim of this preliminary study is to fill this gap.

\section{Résumé}

Cet article présente la preuve de la concurrence frontale d'accès libre qui s'est déroulée sur le marché des services ferroviaires de voyageurs longue distance en Pologne en 2009-2015. Le challenger appartenant au gouvernements régionaux a réussi à augmenter sa part de marché à plus de $33 \%$ (en 2010) mais finalement était forcé à quitter le marché (en 2015) en raison d'un changement soudain de sa stratégie commerciale ainsi que de la pression stratégique de l'opérateur historique sur les décideurs politiques et réglementaires. Ce cas n'a pas encore figuré dans

* Collegium of World Economy, Warsaw School of Economics; mkrol2@sgh.waw.pl. Article received: 3.04.2017, accepted: 28.06.2017. 
la discussion scientifique internationale sur l'accès libre aux marchés ferroviaires de voyageurs en Europe et l'objectif principal de cette étude préliminaire est de combler cette lacune.

Key words: low-cost entry; open access competition; railway transport.

JEL: L51, L92, L100

\section{Introduction}

Evidence of head-on open access competition in passenger rail transport is only recent in Europe. In contrast to competition for the market, where several operators compete for the exclusive right for a specific route or network, the 'open access' competition is in the market, as rivals run on the same route or network. The 'head-on' open access competition means that, in contrast to the niche-oriented, low-scale market entries (which took place in the UK, Germany and Sweden), the new entrants directly challenge the incumbents on important railway connections, including principal ones. As stated by Tomeš et al., such entries have been full-scale with intensive price competition and a clear ambition of winning substantial market shares from the incumbents with lower prices and comparable or even better service quality. They have resulted in an intensive price competition leading to accusations of predatory pricing by the incumbent (Tomeš et al., 2016).

The growing literature on this subject has so far observed evidence of head-on open access competition in Austria (2011-), the Czech Republic (2011-), Italy (2012-), Slovakia (2014-) and Sweden (2015-) ${ }^{1}$. The main aim of this paper is to present a case study of competition which emerged on the market for long-distance rail services in Poland in 2009 when Przewozy Regionalne $^{2}$ (PR), controlled by regional governments, challenged the incumbent operator PKP Intercity (PKP IC).

The successful strategy adopted initially by the newcomer combined lower prices, lower quality and full-scale entry. To some extent it copied therefore the routine of low-cost airlines challenging traditional air carriers, which seems to be one of several distinctive properties of the Polish case. By the strategic use (or abuse) of the political process, PKP IC tried to put its competitor at a disadvantage. The incumbent's strategic behavior included a successful push

\footnotetext{
1 The most recent literature reviews can be found in: Tomeš et al., 2016; Fröidh and Nelldal, 2015.

2 Przewozy Regionalne means literally "Regional Transport Services” in Polish.
} 
to raise the rival's cost of access to the principal railway route in Poland (2013). Strategic lapses of the newcomer contributed largely to its failure in 2015.

However, before failing, in only one year, 2010, the full-scale entry raised PR's market share in the Polish long-distance rail transport services to more than $33 \%^{3}$. It means that more than 18 million passengers were transported by the challenger ${ }^{4}$. It is significant that while the total number of passengers transported by rail in Poland continued its downward trend (dropping by $7.7 \%$ in $2010^{5}$ ), the cut-throat rivalry led to a $4.4 \%$ increase of the transport volume in the analyzed market segment ${ }^{6}$, suggesting pro-consumer effects of competition.

Interestingly, the Polish experience with passenger rail competition has not been analyzed in the official European Commission documents (e.g. European Commission, 2013) ${ }^{7}$, nor in the international business reports on railways in Europe (e.g. IBM, 2011) ${ }^{8}$.

In the next sections, I present the results of my preliminary research on this subject. I describe first what happened in Poland in regard to rail competition (Section II), then briefly discuss this evidence and provide first conclusions (Section III).

\section{Evidence}

Competition in the Polish railway transport services became legally possible in 1997. Yet over the next few years the activities of non-incumbent railway undertakings were in general limited to the local freight services, using mostly

\footnotetext{
3 Passengers (UTK, 2012, p. 25).

4 Based on the data from (UTK, 2011, p. 20-21).

5 From 284 million passengers in 2009 to 262 million passengers in 2010 (UTK on-line statistics).

${ }^{6}$ From 49.3 million passengers in 2009 to 51.5 million passengers 2010 (calculated based on the data from: UTK, 2011, p. 20-21).

7 This highly-quoted study is an impact assessment of an amendment of a crucial regulation for the opening of the market for domestic rail passenger transport services in the EU. It erroneously lists Poland among the countries where the whole market is open through 'open access' but there is no effective competition in the market at the time of writing (European Commission, 2013, p.15).

${ }^{8}$ In this influential comprehensive comparison of the rail markets of the EU Member State, Switzerland and Norway, the PR company has been rightly identified as an 'external RU [railway undertaking]', meaning independent from a government-owned incumbent. Unfortunately, the authors write next: '[a]lthough the market for purely commercial passenger transport is open in Poland, up to now no external RU is active on this segment. Accordingly, the market share in this sector is zero' (IBM, 2011, p. 180-181). This opinion may be justified today, after PR has been thrown away from this market, but certainly not in 2011 .
} 
mining and industrial railway infrastructure. In 2001, a horizontal and vertical break-up of the national rail monopoly PKP (Polish State Railways) gave momentum to the development of lively competition in rail freight in Poland (Król, 2010). For passenger services, however, this was not the case.

The divestiture of PKP resulted in the emergence of a state-owned holding structure called the PKP Group. It included two newly-created nationwide incumbent passenger operators: PKP Przewozy Regionalne (PKP PR) and PKP IC.

The main area of activity of PKP PR was regional rail services performed under a public service obligation (PSO) regime. In addition, the company operated lower-class inter-regional trains (under a separate inter-regional PSO scheme). This class of trains, stopping only at larger towns and skipping most of the stations operated by regional services, has been traditionally called the "fast trains" in Poland".

PKP IC was created to operate higher-class long-distance trains, using national trunk lines connecting Poland's major cities. In other words, the company was set up to provide commercial passenger services. They included two categories of trains: Intercity (IC) and Express (Ex $)^{10}$. The company also operated (and still does) international passenger services. PKP IC was considered a jewel in the PKP Group crown, having the best rolling stock, and was earmarked for eventual public offering.

In 2005, the PKP IC decided it wanted a share of the inter-regional PSO subsidies. For this purpose, it started a lower-class long-distance service branded TLK ${ }^{11}$. Since then, both companies were present in the same market segment of subsidized inter-regional 'fast trains'. However, as they remained within the PKP Group, they did not compete directly. In terms of passengers transported, the PKP PR's share in the long-distance segment was about $75 \%$ and PKP IC's about 25\% (both commercial and TLK services) (UTK 2012, 25). This changed suddenly in 2008.

Unlike PKP IC, the PKP PR was from the beginning considered the "sick man" of PKP Group. Its troubles arose from being heavily overstaffed and equipped with antiquated and inadequate rolling stock at the outset. Its financial position quickly worsened due to problems with financing for the public service obligations. Starting in 2001, the local governments in Poland's regions became responsible for organizing and subsidizing the regional passenger rail services. However, over the years 2001-2003, the subsidies

9 Pociagi pospieszne in Polish.

10 The distinction between the two categories wasn't very clear to customers. The most visible difference between them was that the IC fare, which was a bit higher, included a snack and a hot drink, when the Ex fare didn't.

11 Tanie Linie Kolejowe - literally "Inexpensive Railways" in Polish. 
were realized exclusively by means of a grant given to them by the central government. The problem was that this allowance turned out to be much lower than previously promised to the local authorities. As the exclusive final beneficiary of the grant was PKP PR - the incumbent company on the market for regional passenger rail services in Poland - this contributed to the loss of financial stability and then an acute financial crisis of this enterprise. The central government kept postponing restructuring of PKP PR until 2008, when ownership was transferred fully to the regional authorities. The PKP logo was removed and it became known as Przewozy Regionalne (PR). Crucially, the company's debts have not been fully restructured and it remained heavily indebted.

Additionally, before the company was passed on to the regional authorities, its 'fast trains' services were transferred to PKP IC, which thus became the only operator in the long-distance market. The transfer included all the rolling stock used in the inter-regional traffic, but not all the staff employed in this segment. It meant that PR was removed from a financially viable market segment (the 'fast trains' were under the governmental PSO scheme) and left, overburdened with debt and overemployment, in the unlucrative regions-financed segment of regional services. As the separate regional authorities became collective PR owners only reluctantly, the company's relations with numerous new public shareholders were a further impediment to adopt a coherent strategy.

Still, the company's management took a bold and unexpected decision to seek a way out. In 2009, PR created a new brand called InterRegio and directly challenged the PKP IC incumbent on the important railway connections in Poland ${ }^{12}$. Making additional revenue and improving the company's financial situation was a major objective.

Moreover, entering another market segment allowed PR to make better use of the excessive resources at the company's disposal - staff and rolling stock. Because of the fall in the regional passenger traffic, the company had a considerable number of inactive electric multiple units (EMUs). Using regional EMUs in the long-distance services quickly became emblematic to InterRegio.

This scheme was repeatedly criticized by representatives of PKP IC, who argued that the EMUs had not been designed for this kind of service and that as such they were 'irrelevant and unfit' 13 . The challenger, however, intentionally applied a low-cost, low quality and low-price strategy. While the IC- and Ex-class PKP IC locomotive-hauled trains offered relatively high comfort level, with compulsory seat reservations, restaurant cars etc., InterRegio customers

12 The first InterRegio connection was Warsaw - Białystok in March 2009.

13 In fact, however, PR operated under InterRegio both class EN57 EMUs designed for regional transport and class ED72 EMUs designed for inter-regional traffic. 
often could not be sure if they would find a seat and had to travel standing-up in crowded units. Yet the travel time was similar and the fares much lower. When PR entered the Warsaw - Cracow route, PKP IC fares were 97 PLN in the Ex-class train and $107 \mathrm{PLN}$ in the IC-class train ${ }^{14}$. The challenger set the price at 40 PLN. Travel time was $2 \mathrm{~h} 55$ for the incumbent and $3 \mathrm{~h} 18$ for the newcomer. From the very beginning the InterRegio EMUs were especially crowded on this principal Poland's route. In the customers' opinion, the new service was therefore 'relevant and fit'. And it expanded.

While by the end of 2009 PR operated 23 pairs of InterRegio trains, in 2010 this number increased to 48. In 2011 the service reached all Polish regions. In effect, PR regained around one-third of the long-distance market. In 2009 InterRegio transported 2.6 million passengers, in 2010 as many as 18.2 million and 17 million in 2011. In its most successful year (2010), revenues generated by the new service were 130 million PLN, while its direct costs 80 million PLN (Trammer, 2014). InterRegio became financially sustainable. Several connections were subsidized by the regions, but the bulk of them were purely commercial. At some destinations, InteRegio competed in the subsidized 'fast trains' segment, but the challenger managed to hit the incumbent in its core business or - at least - at what was perceived as its natural zone of activity - the commercial services.

The reaction of PKP IC was dual. On the one hand, as one would expect, it involved pricing. However, the managers of the company decided not to engage in a price war - its regular fares remained at the previous level. Yet, they made a significant change in special offers for the destinations where they faced new competition. They started to market a limited number of seats at 19 PLN (in presale). Before the open access entry occurred, this special offer was available at $59 \mathrm{PLN}^{15}$. In addition other minor offers and adjustments were introduced ${ }^{16}$.

On the other hand, the incumbent engaged in a strategic behavior by using political process to disadvantage the competitor. After PKP PR has been devolved to regional authorities, PKP IC obtained from the government the informal status of the sole 'national operator'. The Minister of Infrastructure, who exercised corporate control, in relation to the company, wrote in August 2009 an official letter to the Presidents of Polish regions acting as owners of PR

14 Both for a $2^{\text {nd }}$ class ticket.

15 It is worth noting that on the routes where competition didn't appear the presale offer remained at the previous level of 59 PLN (Beim, 2009).

16 Among them the PKP IC's train classification was straightened up. The Ex and IC categories were combined into one class, called Express InterCity (EIC). The ex-PKP PR's "fast trains" were finally incorporated into TLK category (standing since 2011 for Twoje Linie Kolejowe - "Your Railways"). 
to express concern about the InterRegio connections being created and posing a threat to the economic activities of PKP IC. In October 2009 the incumbent filed a formal complaint to the railway market regulator - Urząd Transportu Kolejowego (in English: Office of Rail Transport; hereinafter, UTK), accusing PR of unfair competition. According to Trammer, UTK - dependent on the Minister of Infrastructure and led by ex-PKP executives ${ }^{17}$ - sought to find a way to suspend InterRegio connections. The alleged misclassification of the services when ordering train paths was to be used as a pretext (Trammer, 2010). It did not work, but the InterRegio trains were anyway halted by the PKP PLK ${ }^{18}$ infrastructure operator in May 2010 on the grounds that PR was in arrears on its infrastructure charge payments.

This was controversial. The painful financial situation of the regions-owned company was traceable to the years when it was within the PKP Group. PKP PR debts were not fully repaid at the time of its transfer to the new public owners, who inherited a financially distressed enterprise operating in an unprofitable market of regional services. Starting commercial services on the long-distance market was a step towards financial recovery and repayment of debts - including the cumulating overdue track access charges. When the infrastructure operator stopped the profitable Interregio, it was thus depriving itself of the chance that the arrears would be eventually paid. This is why this action has been widely considered to be caused by a different motive: stopping a new rival to the 'national operator' in its tracks (e.g. Trammer, 2010). Not only the infrastructure operator, PKP PLK, was together with PKP IC in the same PKP Group, but also the Minister of Infrastructure exercised proprietary functions in relation to both companies. It is worth noting that the incumbent also had overdue infrastructure access charges - yet its trains have not been stopped $^{19}$.

PR's long-distance services were resumed after a month, when a debt repayment schedule was set. Interestingly, despite a monthly break in operations, 2010 was the best year in the InterRegio history. The next year was almost as good - but in 2012 the operations fell by $60 \%$, with less than 6.7 million passengers transported. It seems, however, that it was less due to the incumbent's strategic countermeasures, but to the challenger's strategic error of abandoning the successful initial strategy.

17 A detailed analysis of the fundamental conflict between the government's regulatory, proprietary and economic functions concerning the railway market in Poland can be found in (Król, 2010).

18 PKP Polskie Linie Kolejowe - PKP "Polish Railway Lines" in Polish.

19 As well as the PR's regional trains: unlucrative and generating overdues in infrastructure access charges. 
According to Biega, who co-authored the PR's initial strategy (2009-2011), the original game plan was a low-cost entry into the routes where the number of passengers was large and where it was possible to offer travel time comparable to both PKP IC and road transport. The examples were Warsaw - Cracow, Warsaw - Poznań or Poznań - Toruń - Olsztyn (Z Biegiem Szyn, 2015). Very competitive fares, which attracted many customers, were conditioned by low operating costs thanks to the deployment of the EMUs. The quality of service was relatively poor, which is an inherent attribute of a 'no-frills' strategy. Such a strategy had been consciously adopted by the challenger.

Unexpectedly, starting in the 2011/2012 20 timetable offer, PR abandoned this approach. The new management decided to improve the quality of service by offering better travel comfort. The company started replacing class EN57 EMUs with locomotive-hauled trains. This, however, generated costs. Sixteen passenger cars were thoroughly modernized, including fitting them with air conditioning, LCD screens and wireless internet service. PR did not own locomotives, so it had to rent them. Moreover, because of their greater axle load, locomotive-hauled trains incurred larger track access charges. Suddenly, PR's managers found themselves on the verge of losing financial sustainability of the long-distance offer.

As the bulk of InterRegio services were commercial, raising fares to maintain profitability was unavoidable. Prices of tickets increased by up to $40 \%$, depending on a route. This caused a customer outflow. But ticket sales were also reduced by another factor. As Trammer writes, more and more connections were operated intermittently - on selected days only. For instance in the 2012/2013 timetable, 52 of the 113 trains were episodic (e.g. on Mondays only). This made the offer less transparent and attractive to customers (Trammer, 2013).

Furthermore, the approach to planning new connections changed. As Biega stresses, the focus was no longer on the routes with the largest number of passengers. On the contrary, the company started to introduce InterRegio services where it was clear that they would not be financially viable. Also, the challenger ceased to be reactive - PR stopped adjusting offers to changes in demand on the routes (Z Biegiem Szyn, 2015).

Consequently, the number of passengers transported by InterRegio trains decreased dramatically in 2012 and never increased subsequently. At the same time the service ceased to be financially sustainable.

20 A new timetable starts in Poland on the December's second Sunday. 
As with many examples of spectacular business mistakes, it is hard to explain why PR's management adopted this new strategy. I It is clear, however, that the business culture embedded in the operator's core segment of regional services, with direct focus on gaining subsidies rather than passengers, prevailed.

The next act of the InterRegio drama took place at the end of 2013. By using strategic influence with regulators, PKP IC managed to raise its rivals' cost on the principal railway destination Warsaw - Cracow $(317 \mathrm{~km})$. The challenger operated class ED72 EMUs on this route designed for inter-regional traffic at $110 \mathrm{~km} / \mathrm{h}$. The key section of the Warsaw - Cracow route uses the $\mathrm{CMK}^{21}$ line $(224 \mathrm{~km})$. The CMK, completed in 1977 , was designed for $250 \mathrm{~km} / \mathrm{h}$, but never operated at this speed ${ }^{22}$. In 2013 the maximum speed was of $160 \mathrm{~km} / \mathrm{h}$ reached by the PKP IC trains ${ }^{23}$.

Unexpectedly, starting with the 2013/2014 timetable, PKP PLK infrastructure manager - the incumbent's sister company in the PKP Group - introduced the minimum speed requirement for the $C M K$ at $120 \mathrm{~km} / \mathrm{h}$. The rail market regulator UTK voiced no objection and PR's low-cost EMUs were no longer allowed on the tracks. The challenger had to introduce locomotive-hauled trains on the route resulting in losses on this destination. According to Trammer, the track access charges themselves increased by 0.2 million PLN per pair of trains (Trammer, 2014). As a consequence, by the end of 2014 the InterRegio Warsaw - Cracow service was closed.

Eventually, at the end of August 2015, the PR company ended the provision of long-distance commercial passenger services in Poland. The disastrous financial situation in the regional operations was pivotal to the decision. PR was on the verge of bankruptcy and by the end of 2015, the controlling interest in the company has been taken over by a governmental restructuring agency. One of the conditions required to obtain public aid was to remove the commercial InterRegio services.

"Order was restored" on the market and the 'national operator' no longer had to struggle with an unwanted rival. At the time of writing, the PR's subsidized Warsaw - Lódź services ${ }^{24}$, which survived under the InterRegio logo, are but a distant memory of the fierce head-on open access competition that used to take place in Poland's long-distance passenger rail services.

21 Centralna Magistrala Kolejowa - Central Trunk Rail Line in Polish.

${ }^{22}$ In 1994 a Pendolino train reached here $250,1 \mathrm{~km} / \mathrm{h}$ during a high-speed test. By the end of 2013 a new Pendolino ED250 reached $293 \mathrm{~km} / \mathrm{h}$.

23 Only starting 2014/2015 timetable PKP IC begun regular operations using Pendolino trains at $200 \mathrm{~km} / \mathrm{h}$ and branded 'Express Intercity Premium' (EIP).

24 This connection is subsidized by the Łódź Region. 


\section{Discussion and conclusions}

The case study presented above is interesting for many reasons. PR, an incumbent company in one market segment (regional services), challenged PKP IC, an incumbent company in another market segment (long-distance services). Both companies have been public sector-owned entities: PKP IC is a classic state-owned enterprise (SOE), while PR was at that time a regions-owned enterprise ${ }^{25}$. Therefore the full-scale open access competition involved two state-owned rivals from the same country. That is, the entry was not by a private challenger (as it was in the Czech Republic) or from abroad (as in rail freight in the UK).

Both companies obtained public service contracts (PSCs) in their core market segments. It is unclear, and needs further research, whether they used them to cross-subsidize commercial long-distance services subject to head-on competition.

PR was operating simultaneously in two market segments, but the company's conduct was extremely different in each of them. In the quasi-monopolistic segment of regional services, where PR was the dominant entity, its conduct could be a textbook example of a managerial slack, with a clear focus on gaining subsidies rather than passengers. In the long-distance segment subject to competition, the company's behavior (2009-2011) was profit-oriented and aggressive, with an ambition to attract as many passengers as possible. The difference was apparent even at the first sight: the staff was more courteous and trains cleaner in InterRegio compared to Regio ${ }^{26}$. This led to a grotesque situation: at the same time the PR logo stood as a symbol of an irredeemable monopolistic SOE being a relic from the past and - in the other market segment - as the driver of desirable changes in the Polish rail sector.

All full-scale open access entries in the railway passenger markets described in literature used a strategy involving lower prices and comparable or even better service quality. The Polish case differs significantly, as PR used a full-entry strategy based on both lower prices and lower service quality. Interestingly, according to Tomeš et al., such approach has so far been typical rather of low scale-entries, targeting small, neglected market segments (Tomeš et al., 2016).

The "no-frills" strategy enabled the company to favorably segment the market of long-distance services. The group of customers who were much more sensitive to price than to service quality turned out to be large. Focusing

25 At the time of writing it co-owned by the Polish regions, as the controlling interest in the company has been taken over by a governmental agency.

26 Such opinions of InterRegio and Regio customers are still to be found on the Internet. 
on them was the successful initial (2009-2011) policy. However, the price sensitivity of the customers came out finally to be a two-edged sword. Lifting costs for the sake of the higher service quality called into question the main source of the company's strategic advantage (2012-). The unavoidable price increase resulted in the natural outflow of price-sensitive customers, to whom the service quality was not essential. Unfortunately, it was the core clientele of the operator.

Another feature of the case is that despite of what theoretical studies and experience from other countries may suggest, a fierce price war between the challenger and the incumbent did not happen. Apparently PKP IC decided that a price war was a dangerous game and should not be deployed before other options are exhausted. The PKP IC management used a typical weapon of an enterprise enjoying the status of "a national provider" - political influence. Using it was facilitated by the fact that the challenger's entry was not "assisted" by a government eager to open up the market. PKP IC was thus able to engage in a strategic behavior without running the risk of jeopardizing government objectives. The evidence from Poland confirms that a strategic use of political process is a method for disadvantaging competitors that can be easily available to an incumbent $\mathrm{SOE}^{27}$. The PKP IC's strategic behavior included a successful applying of the raising rivals' costs strategy. As expected, it proved to be an extremely effective routine against a low-cost operator.

The analyzed case can be considered as one of the first, if not the first, examples of head-on open-access competition in passenger rail transport in the EU. The rise and fall of InterRegio services is very instructive but still little known and investigated. It undoubtedly deserves further research.

\section{Acknowledgement}

This research has been supported by Collegium of World Economy, Warsaw School of Economics (KGS/S17/05/2017).

\section{Literature}

Beim, M. (2009), InterREGIO impulsem do przemian rynkowych? Retrieved from www. sobieski.org.pl (28.06.2017).

European Commission, 2013. Impact Assessement accompanying the documents: Proposal for Regulation of the European Parliament and of the Council amending Regulation (EC)

27 What is a serious and often undervalued argument in favor of their privatization. 
No 1370/2007 concerning the opening of the market for domestic passenger transport services by rail [and] Proposal for a Directive of the European Parliament and of the Council amending Directive 2012/34/EU of the European Parliament and of the Council of 21 November 2012 establishing a single European railway area, as regards the opening of the market for domestic passenger transport services by rail and the governance of the railway infrastructure, Brussels 2013.

IBM (2011). Rail Liberalisation Index 2011. Market opening: comparison of the rail markets of the Member States of the European Union, Switzerland and Norway. IBM Deutschland GmbH, Brussels 2011.

Fröidh, O. and Nelldal, B.-L. (2015). The impact of market opening on the supply of interregional train services. Journal of Transport Geography. 46, 189-200, https://doi. org/10.1016/j.jtrangeo.2015.06.017

Król, M. (2010). Liberalization without a regulator. The rail freight transport market in Poland in the years 1996-2009. YARS, 3(3), 165-178.

Tomeš, Z., Kvizda, M., Jandová, M. and Rederer, V. (2016). Open access passenger rail competition in the Czech Republic, Transport Policy. 47, 203-211, https://doi. org/10.1016/j.tranpol.2016.02.003.

Trammer, K. (2010). Zamach majowy, Z Biegiem Szyn. 3(47).

Trammer K. (2013). Początek końca InterRegio?, Z Biegiem Szyn. 1(67).

Trammer K. (2014). Pociąg do strat. Jak połączenia InterRegio zepchnięto na boczny tor, Z Biegiem Szyn. 6(74).

UTK. (2011). Funkcjonowanie rynku transportu kolejowego w Polsce w 2010 roku, Urząd Transportu Kolejowego (Railway Transport Authority): Warsaw.

UTK. (2012). Funkcjonowanie rynku transportu kolejowego w 2011 roku, Urząd Transportu Kolejowego: Warsaw.

Z Biegiem Szyn, 2015. Interview with Stanisław Biega, Z Biegiem Szyn. 5(79). 